\begin{tabular}{|c|c|}
\hline DE GRUYTER & ECONOMIC THEMES (2015) 53 (4): 449-466 \\
\hline & DOI $10.1515 /$ ethemes-2015-0026 \\
\hline
\end{tabular}

\title{
HOW GOVERNMENT CREATES VALUE?
}

\author{
Fred Thompson
}

Atkinson Graduate School of Management, Willamette University, Salem OR, USA

\thompso@willamette.edu

\section{Polly Rizova}

Atkinson Graduate School of Management, Willamette University, Salem OR, USA \prizova@willamette.edu

UDC

344.021:351

Review paper

Received:

24.11.2015

Accepted:

17.12.2015

\begin{abstract}
Private enterprises should be concerned with maximizing productivity. Government should be concerned with minimizing risk, perhaps subject to a cost or productivity constraint. Value creation in government ought to strive for consistency, coherency, and transparency. Achieving consistency and coherence in the face of systemic and idiosyncratic risk calls the elaboration of general risk assessment model, which takes account of the various kinds of risk confronted by the diversity of government institutions. Lacking such a model, the best we can hope for is the design and execution of policies and practices that assure reasonably satisfactory outcomes no matter what the future throws at us.
\end{abstract}

Keywords: Process, Mechanism, Government spending and taxing, Risk, Systemic risk, Public management

\section{Introduction}

We teach at a generic school of management. We teach that all enterprises are public and that all enterprises exist to create public value, not just governmental and not-for-profit organizations, but businesses as well. Consequently, it is our position that all of the training we offer is for public service, although we offer electives that are tailored specifically to the requirements of governmental, business, or not-for-profit enterprises. 
What this doctrine omits is a definition of the meaning and nature of public value, an explanation of the distinct roles assigned the sectors with respect to public value creation, and a description of arrangements that govern the creation and delivery of public value. In this paper, the meaning and content of public value is defined, how government and business create public value is shown, and briefly explain why their governance arrangements work the way they do. We shall deal first with business and then the government.

\section{Value Creation Equals Benefits Minus Costs}

Administrative inquiry is inherently ethical inquiry. It is concerned with taking good actions and avoiding bad ones. Of course, administrative inquiry is not only ethical inquiry. The process of crafting appropriate and effective responses to administrative problems also implies an abiding concern with their workability and practicality. Nevertheless, to act rationally, it is first necessary to comprehend the desirability of the ends sought (i.e., value). Lacking this knowledge, leaders cannot engage with others in effective argumentative exchange about the shape and content of collective actions or make sense of their intellectual performances retrospectively. Administrative inquiry calls, therefore, for explicit attention to the meaning and nature of public value.

Our definition of value creation is explicitly instrumental and operational: value is created where benefits, by convention measured in terms of willingness and ability to pay on the part of the members of the public who enjoy them, exceed costs, measured in terms of willingness and ability to sell on the part of those who give up things used to create value. In other words, value creation involves the sacrifice of valued things to create things of greater value. Maximizing public value means maximizing net benefit to the public from the enjoyment of existing endowments of resources and amenities. ${ }^{1}$ Value creation is a flow concept. Values are created and enjoyed over time. These flows can be increased or reduced by adding to our stock of endowments or by depleting them. Like any flow that can be measured in monetary terms, future values can be represented as stocks by means of present value analysis. Although, because the future is inherently uncertain, imperfectly so.

\footnotetext{
${ }^{1}$ The instrumental ethic outlined here is basically utilitarian. In assessing whether a proposed state is preferable to an existing one, it is necessary to consider the consequences for those affected. For folks with large, well-diversified asset portfolios, Kaldor-Hicks (the winners could compensate the losers and still be better off) is an eminently satisfactory assessment criterion. For folks with small, ill-diversified asset portfolios, winners must compensate losers; otherwise value creation is iffy.
} 


\subsection{Creation of value by business}

What should business leaders do? The simple answer is the same for leaders of all enterprises, make things better (i.e., convert existing conditions into preferred conditions, thereby creating value). How? According to Milton Friedman "the enlightened corporation should try to create value for all of its constituencies," which he claims is equivalent to saying "the social responsibility of business [is] to increase its profits" (Friedman, 1970: 32). ${ }^{2}$ While he qualifies this statement with the caveat that the proper scope of business is restricted to legitimate or lawful activities and acknowledges that it may well be "in the long run interest of a corporation that is a major employer in a small community to devote resources to providing amenities to that community or to improving its government" (Friedman, 1962), it should be understood that, in practice, the pursuit of profit all too often reflects an impoverished notion the meaning of value creation. ${ }^{3}$ Nevertheless, it makes sense to explain how in theory the pursuit of profit can create public value.

Insofar as value creation is concerned with private goods (those characterized by exhaustibility and excludability) provision, the public is made up of consumers and producers. We are consumers when we buy and enjoy goods and producers when we make and sell them. Given a reasonable numbers of buyers and sellers, pursuit of self interest on their parts is consistent with the maximization of consumer and producer surpluses (i.e., maximization of net benefits).

Businesses are social constructs. They are collectivities that exist for the sole purpose of providing good things (things people need or want, where wants reflect willingness to pay). They buy or rent resources from factor (i.e., land, labor, capital, knowhow) suppliers and use those resources to provide things that they sell or rent to others. Given that folks who sell goods and services to

\footnotetext{
${ }^{2}$ That is not our school's doctrinal position. We argue that business leaders should assess all actions in terms of the value they can be expected to generate for everyone affected by them. Hence, the main difference between our view and the assessment practices recommended in most corporate finance texts goes to the question of standing: whose benefits and costs count and how much? Corporate finance texts usually argue that project selection should be governed solely by the criterion of maximizing shareholder value. In contrast, we argue that business leaders should also take account of the spillovers or externalities, positive and negative, their actions create (Maltz, Thompson, Ringold, 2011). Ultimately, of course, it may well be that the differences between our position on the standing question and Friedman's are for the most part rhetorical. But, rhetorical differences are highly relevant to administrative inquiry. It might be noted that Friedman's argument actually has little to do with standing, but instead goes to the competence of business leaders. Implicitly, Friedman accepts that business leaders are boundedly rational and boundedly moral, which is an argument for specialization and transparency. He claims that their comparative advantage lies in making financial, marketing, and operating decisions and concludes that is what they should do. This is positive claim. Interestingly, he sees no need to back it up with evidence.

${ }^{3}$ Tax avoidance, investments in lobbying, and various other rent-seeking behavior produce benefits to shareholders (see, Mathur, Singh, Thompson, \& Nejadmalayeri, 2012) but are usually value reducing overall (i.e, they produce negative net benefits).
} 
businesses and who buy from them pursue their own interests, businesses maximize public value by maximizing the difference between their payments to factor suppliers and their payments from their customers. We call this difference, profit. Business owners claim this difference or, in the case of publically held corporations, shareholders do. Hence, where publically held corporations are concerned, public value maximization means maximizing shareholder value. Economists further justify this norm by referencing Irving Fisher's separation theorem, which argues that shareholders should care only about a business's profitability and not the means by which it is realized. ${ }^{4}$

Profitability is not a straightforward concept, however. The process of value creation takes place over time and it involves risk. Time per se can be finessed by saying that profit maximization means maximizing net present-value benefits to shareholders. After about a century of debate, we have determined that this usually means maximizing the present value of future free-cash flows thrown off by inventory turnover, ${ }^{5}$ which resolves the recognition question (when to count performance), as well as the standing question (whose benefits count).

Risk is a tougher matter entirely. The only way competitive businesses can create value is by increasing their productivity over time: by creating new or improved products or services that increase value to current consumers, or by finding new consumers who value current products, or by finding better, more efficient ways of delivering them. This process is destabilizing. Growth, learning, and creating value thereby require perturbation and measurement. It is inherently risky. Sometimes initiatives succeed; more often they fail. As a consequence, some businesses are highly profitable and others are not, due entirely to their idiosyncratic efforts and the luck of the draw. On average this process creates a lot of public value. It is the primary engine of economic growth and development. Nevertheless, this value creation entails a lot of risk. As David Frum (1994: 4) observes:

The great, overwhelming fact of a capitalist economy is risk. Everyone is at constant risk of the loss of his job, or of the destruction of his business by a competitor, or of the crash of his investment portfolio.

\footnotetext{
${ }^{4}$ This assumption seems self evident, but it is not necessarily valid. Shareholders often appear to have preferences for things other than the properties of a business's returns. "Social responsibility" may be an example. A preference for profitable fast-growing businesses (growth stocks) is probably a better one. That some investors get utility from owning these stocks (being connected to a "winner"), although they tend to be poorer investments than value stocks, is one possible explanation for the anomalous market premium they command.

${ }^{5}$ This norm does not apply to all businesses, banks, for example, create value by holding financial inventories; using equity, risk pooling, and hedges to manage inventory risk. It is not unreasonable to suggest that many of them got into trouble precisely because they lost sight of this purpose and instead got caught up in maximizing yields.
} 
Most people want and need stability. Consequently, people tend to be averse to risk, shareholders included, some more, some less. Nevertheless, to the extent that shareholders can diversify away enterprise-specific or idiosyncratic risk, they ought to be largely indifferent to it and, once they have aligned their investment portfolios with their individual risk preferences, they should care only about average returns. In theory, diversification means that business leaders can ignore the identities of their shareholders and their individual risk preferences and concentrate on increasing productivity, which will be maximized where they pursue every project that offers positive, expected net present-value benefits. ${ }^{6}$

For the community as a whole, maximization of productivity means higher levels of economic growth and development. Ultimately, the average rate of productivity growth is far more important to the welfare of a community than its volatility. Even a small change in growth can easily outweigh the value of a large (opposite) change in the variance in economic product (Lucas, 1987). Small changes in growth rates can translate into enormous changes in wellbeing. America's average rate of growth in per capita GDP from 1880 to 2010 was 1.8 percent, doubling it every forty years, producing an eightfold increase over that interval. Were that rate increased by even half of a percentage point, however, doubling would have occurred every thirty years - in which case per capita GDP would be twice what it is now. Business is the main engine of economic growth. But an engine needs a flywheel. Business does not and cannot provide stability.

\subsection{Creation of value by government}

Where government enterprises are concerned, scholars and practitioners often associate the pursuit of public value with increasing productivity - with efficiency and effectiveness. Increasingly, however, we have become convinced that this view profoundly misconceives the fundamental purpose of governmental enterprises.

This realization came hard for us. It is not that we thought there was no difference between public and private enterprises - that we could privatize all government services or nationalize all businesses, to paraphrase Hal Rainey -, but there are a number of business disciplines - financial economics, managerial accounting and control, and marketing - that we thought could help government enterprises increase throughput or design and execute new and better services (e.g., Barzelay and Thompson, 2006). In any case, we believed the central tenet of the New Public Management (NPM), that if we ransacked those disciplines,

\footnotetext{
${ }^{6}$ In practice, the covariant factors that generate systematic risk and their loadings are unstable over time. Consequently, the portfolios that investors must hold to fully diversify their holdings are huge, variable, and intractable. There are no perfect hedges.
} 
we would find artifacts that could be usefully applied in government to improve productivity. In point of fact, events have generally falsified our belief.

The interesting question is why? NPM's flaw was not hubris or overreach. It was understood that it addressed a small part of the broader field of public policy and administration, the part concerned with answering the following kinds of questions: What is the role of public managers? What should be the design of a programmatic organization? How should government operations be led? What public management policies (e.g., financial management, human resource management, procurement, etc.) should be chosen?

We are inclined to think that NPM's flaw lay in its execution: we ransackers all too often failed to do an able job of extrapolation from source sites to target sites (Barzelay, 2007) owing to a fundamental misunderstanding of government's role in a capitalistic economy. NPM was focused exclusively on productivity maximization, when that is, in fact, secondary to the governmental enterprise.

Instead, stabilization is the state's primary role (Moss, 2004). Governments create value by performing a variety of functions: establishing stable institutional frameworks that allow markets to work effectively, reducing the volatility of business cycles, thereby dampening systemic risk, providing an array of risk-spreading, transfer programs aimed at mitigating idiosyncratic individual and collective hazards, and underwriting the provision of various vital services - services which might otherwise often be unavailable precisely when most needed. Under contemporary economic theory, the basic market failure is the absence of a full set of Arrow-Debreu contingent-claims contracts, often due to missing or asymmetric information, which typically takes the form of adverse selection or moral hazard problems. In this sense, all the functions performed by government are addressed to market failure and, as increasing functions of risk aversion and wealth, potentially value creating.

Stability is something people want and often need. It is one thing business cannot deliver. Government can. Indeed, value creation throughout the economy depends on stability provided by governmental enterprises. In a sense, once the boundaries of the night-watchman state have been breached, "government is," in Paul Krugman's words, "essentially a huge insurance company with an army" (NYT, 4/8/10).

Of course, businesses do sell insurance, but the fact of the matter is that not all risks are privately insurable - businesses cannot make money insuring against them. Private insurance is helpless in the face of systemic risk and is often defeated by size, ${ }^{8}$ adverse selection, moral hazard, and/or missing

\footnotetext{
${ }^{7}$ Michael Barzelay (2001) formulated this statement of the public management agenda.

${ }^{8}$ Robert Shiller (1998) argues that modern financial engineering could overcome the size problem. While we find many of his arguments intellectually compelling, we are not persuaded overall. $\mathrm{He}$
} 
markets. Hence, it follows that: government creates value when it can forestall or mitigate risks that are not privately insurable for less than we are collectively willing to pay to be protected from them.

\section{Stabilizing the Economy}

Economists usually note that one of the vital functions of government is the provision of an institutional framework for the economy. These comprehend a set of rules or standards that makes markets more understandable/predictable and, thereby, reduce transactions costs, often greatly. These rules define property rights and obligations (for example, what constitutes theft or trespass?), specify the nature and enforceability of contracts (for example, what is fraud?), provide a system of money and banking, establish standardized weights and measures, and the like. As the economy becomes more complex, so too must these rules. But their importance was evident to America's founding fathers. Article I of the Constitution explicitly authorized the Congress to make such rules. The Congress's first order of business, after it established is own rules of procedure and provided for the enactment of a Bill of Rights, was the incorporation of the English common law governing property and contracts into American law.

In many cases, the content of these rules is less important than their existence, transparency, and stability, although they might have significant distributional consequences. To cite a familiar example, it does not much matter which side of the road we drive on, as long as we drive on the same side.

Government can also create value by information provision and dissemination - indeed, this describes much of what it does, although we do not have a very good understanding of the processes by which information/ knowledge is created and shared or the mechanisms through which learning takes place. Knowledge is valuable when it reduces uncertainty allowing better actions than would otherwise be taken. In other words, knowledge provision increases the probability that net gains will be realized or reduces the likelihood of net losses. Like standard setting, it has the effect of reducing the variance in outcomes (risk) and increasing average payoffs and, often, these mechanisms are complementary.

Macroeconomic stabilization is another, albeit more controversial, mechanism through which government can create value, potentially a lot of value, in this instance by reducing systemic risk (covariant volatility). Averting the Great Recession, for example, would have prevented at least \$6 trillion of lost output. Ending it could forestall further losses of $\$ 3$ trillion. Moreover,

implicitly asks us to distinguish idiosyncratic risks from systemic ones and we do not think that possible ex ante. 
there is a second mechanism through which macroeconomic stabilization can create value. Reducing macroeconomic volatility evidently increases economic growth, not just compound growth rates, but also their arithmetic average (Ramey and Ramey, 1995), probably because of the effects of systemic volatility on business investment. Booms promote unbalanced investment; busts delay the pursuit of beneficial projects.

A potential for creating value does not, of course, guarantee that potential will be realized. Doubtless the U.S. government has the tools needed to smooth out booms and busts. Moreover, their execution is costless when done properly. For example, the U.S. Federal Reserve Bank (the 'Fed') has the authority and the know-how to set monetary policy by targeting a stable trend line of growth in nominal GDP. The U.S. Treasury can mitigate the consequences of unanticipated negative shocks by printing money; asset booms can be moderated by tax increases. However, big shocks, whether exogenous or endogenous, negative or positive, call for prompt discretionary action. Except under extraordinary conditions, like the outbreak of World War II, speedy decision making is not an attribute of the American system of government.

Avoiding a crisis is usually better than repairing its effects (Kunreuther and Pauly, 2006). Averting a crisis, however, always requires timely action. Unfortunately, even where government officials possess the authority needed to act, their repertoire of responses may be inappropriate to the situation at hand. In 2008, for example, the peculiar nature of the financial panic required the Fed to play the role of broker-dealer of last resort, an uncomfortable and unfamiliar role. As a consequence its interventions were too often a day late and hundreds of billions of dollars short. A similar diagnosis can be made with respect to its failure to prick the real-estate bubble few years earlier.

Nevertheless, that government could have done more or better does not mean that it has not created a lot of public value through its efforts to manage systemic risk (Grunwald, 2012).

\section{Protecting Individuals and Families}

Much of what happens to people, both the good and the bad, is due entirely to their idiosyncratic efforts and the luck of the draw. People are generally risk averse. That means that they fear the bad more than they value the good, which means that balancing the two is not simply a matter of smoothing let alone averaging consumption over time, although, of course, talking about balancing goods and bads requires a common measure. As practical matter, that means money, the closest thing we have to a universal ruler. Savings are one way that individuals can protect themselves against bad outcomes. They can consume less, putting aside a portion of their income for a rainy day - as Wildavsky $(1980,1981)$ put it, richer is safer. Insurance is another way for individuals to 
even things out. By definition, where things are measured in monetary terms, risk aversion implies that the expected payout from insurance must be less than the present value of the premiums, but the necessary premiums required to offset random risks are also usually less than the savings needed to provide equivalent peace of mind.

Unfortunately, risks are privately insurable only insofar as outcomes are due to the luck of the draw. We have already noted that covariant or systemic risks are privately uninsurable, although paradoxically they can be managed by very large, relatively closed economies. The same is true of death, poverty, unemployment, sickness, and disaster - many of the things people fear most. Behind a veil of ignorance, their monetary consequences are all theoretically privately insurable. As a practical matter, private markets are too often defeated by private information, leading to adverse selection, moral hazard, and/or missing markets.

Public transfer programs supplement or replace private savings and insurance. Social Security payments, for example, amount to more than half the income of two-thirds of the recipients. These payments last until death and are guaranteed against financial-market fluctuations and inflation. Consequently, they are especially valuable both to their beneficiaries and to macroeconomic stability during periods of severe economic stress, like the one we have lived through these past few years (Patashnik, 1996). Private insurance cannot provide similar security.

The undesirable consequences of private information can be reduced by making insurance programs universal or nearly so. Making old-age insurance mandatory mitigated the problems of adverse selection, which made private oldage insurance prohibitively costly to the folks who needed it (as a general rule, people who can afford private old-age insurance don't need it). Extending Medicare to the entire population of the U.S. would have a similar effect (this is the logic underlying Obamacare's individual mandate). Standardizing these programs can also reduce delivery costs. Nevertheless, while the costs of universal, public programs are less than they would be, if they could be provided through private insurance, total outlays necessarily exceed transfers. Moreover, these programs have additional costs. Making them universal does not mean that the private-information problems, which defeat private markets, miraculously disappear. Moral hazard remains a problem, because the risks offset by transfer programs still depend in large part on individual effort and not just the luck of the draw. Reducing the adverse consequences of "bad" things for the folks who are in the best position avoid them means that more "bad" things are likely to happen. Again, citing Frum (1994: 4):

Risk makes people circumspect. It disciplines them and teaches them self-control. Without a safety net, people won't try to vault across the 
big top. Social security, student loans, and other government programs make it far less catastrophic than it used to be for middle-class people to dissolve their families. Without welfare and food stamps, poor people would cling harder to working-class respectability than they do now.

Finally, when transfers are supported by taxes they create deadweight losses, including out-of-pocket collection and avoidance costs (Diewert, Lawrence, and Thompson, 1998).

Conceptually, therefore, it makes sense to think of public spending on transfer programs as negative taxes. Doing so would tend to promote coherence and consistency, not only from a macroeconomic point of view, but also in terms of their effects upon private saving, consumption, investment, and fairness overall (Buiter, 1990; Mirrlees et al., 2012).

Indeed, one might argue that government regulation of business aimed at increasing health and safety has identically the same insurance function as transfer programs (Viscusi, 1994; Keeney, 1997). The only difference between these programs and transfer programs is that they are less transparent, owing to the fact that collections and payments do not go through the public fisc. Presumably, they too should be subject to similar standards of coherence and consistency (Thompson, 1997; see, however, Meyers, 1998).

\section{Locally Provided Services}

Municipal corporations have a lot in common with business corporations. Given the spatial aspects of locally provided services, a case can be made that property owners are equivalent to shareholders and that municipal officials create value by maximizing property values within a jurisdiction's boundaries via development management (planning, organization, etc.) and the provision of an array of services and amenities that can be more efficiently financed collectively than by individual property owners (Breton, $1977 \&$ 1996). This basic logic seems to underlie most local service-delivery arrangements (Hefetz and Warner, 2012) as well as local reliance on user fees and property taxes, which, where assessments reflect market prices, are the economic equivalents of user fees. One might conclude, therefore, that once the mix of municipal services is decided, value creation through service provision is simply a matter of increasing throughput or productivity.

It is not. From a risk standpoint, there is a big difference between holding property and holding shares: most citizens of a municipality cannot diversify their real-estate portfolios. This means that stability of service delivery can have extraordinary value to citizens, especially under certain specified circumstances. It is axiomatic that asset values depend both on payoffs in future states and on the relative payoff in those states. Service failures that occur in catastrophic 
states ought therefore reduce current asset values much more than where they are negatively correlated with systemic risk. Fire departments, for example, primarily protect property holders from catastrophic fires that get out of control, destroying whole neighborhoods or even cities. Consequently, they are nearly everywhere supported by mandatory levies, often property taxes, even where the services are provided by competitive businesses, as in Denmark.

Consequently, when one talks about value creation through provision of local services, the appropriate question is, "how can we get a good result no matter what the future throws at us?" A good answer must stress two things: that many of these services are essential - water, waste removal, streets, police and fire protection, etc. - and dependability. Provision cannot be permitted to fail when needed; essential services are, by definition essential and most needed precisely when the greatest demands are made upon them.

\section{Instead of conclusion: So What?}

This paper argues that government creates value by promoting stability, where stability is understood in terms of reduced volatility or variance in payoffs/outcomes. This implies that government has a clear-cut objective function: minimize risk, subject to cost and delivery constraints. My argument is largely self-evident. People commonly talk about public values and purposes in terms of safety, order, and security. Or, as Tony Judt put it, we "have active interventionist states protecting us against things that frighten people" (Judt and Božić, 2010:11).

This nearly universal understanding of government value creation can be cloaked in somewhat more formal language - mitigation of systemic and idiosyncratic risk - instead of the everyday language of safety, order, and security. O'Toole and Meier take this logic a step further (2012). They propose theory of government enterprise that explicitly presumes that government enterprises maximize stability. Specifically, they posit an output vector at time $t$ or $\mathrm{Y}_{t}$, and propose that current performance is a stochastic function of past performance at time $t-1$ :

$$
\mathrm{Y}_{t}=s\left(\mathrm{Y}_{t-1}\right)
$$

In turn, function $s$ reflects of a set of stabilizing features of organizational systems and buffers (standard operating procedures, budgets, civil service rules, and the like), $\mathrm{O}$,

$$
\text { Min } \mathrm{s}_{\text {var }}\left\{\mathrm{Y}_{t}=s\left(\mathrm{Y}_{\mathrm{t}-1} \mid \mathrm{O}\right), s=h(\mathrm{O})\right\}
$$

If one accepts this distinction, what are its implications for the study of public policy and administration? There are several. 
First, it provides a bright line, which unambiguously distinguishes the aspirational purposes of government enterprises from those of private enterprises. Private enterprises are primarily concerned with maximizing productivity. Government is primarily concerned with minimizing risk subject to a productivity constraint. Bright lines have two sorts of benefits for scholars. They help us to understand how things on the same side of the line work and how they differ from those on the other.

Most students of public finance, for example, draw the line about where we do and for similar reasons: aside from the provision of a basic set of economic institutions or framework, the proper functions of government are macroeconomic stabilization, income redistribution, and the provision of 'public' and 'merit' goods. They put the line where they do because they can see that non-governmental enterprises rarely perform these functions and deduce that their performance could make people better off - create states in which winners would have the wherewithal to voluntarily compensate losers for their losses. ${ }^{9}$ Nevertheless, under the standard formulation, stabilization, redistribution, and service provision remain separate, disparate categories. In contrast, the line proposed here implies that these functions reflect a single, coherent underlying logic, which permits scholars to better understand tradeoffs and complementarities between the functions. In other words, this line is better precisely because it is brighter.

A further intellectual advantage of a distinction rooted in institutional purpose is that it clarifies the difference between business and government. Clarifying this difference should help scholars distinguish reliable argumentative pathways for extrapolating insights from business disciplines like finance and managerial accounting and control to public administration (see, for examples, Hammitt, et al., 1999; Thompson and Gates, 2007; Dothan and Thompson, 2009a \& 2009b) and vice versa from those that lead nowhere.

Second, this analytic distinction can help scholars make interesting, surprising causal or instrumental claims about governmental behavior. To make predictions about behavior, one must presume that it is either habitual or instrumental. A model of enterprise behavior based on the latter presumption necessarily starts with purpose. Certainly, much of what government does seems to be designed to bring about order to what would otherwise be chaotic: standard setting, coordinating networks, tracking and incapacitating threats, reducing individual vulnerabilities, and moderating the consequences of adverse events, by investing in before-the-fact activities - diversification measures to improve risk preparedness, risk pooling, etc. - and providing programs for recovery and reconstruction after the fact. Moreover, the history of government

${ }^{9}$ While the logic may seem tortured to some, this is true even of redistribution (see, Hochman and Rodgers, 1969). 
regulation in the U.S. is that major initiatives follow catastrophic events. But citing government's functions begs the behavioral question.

Does a distinction focusing on stability help scholars make sense of existing governance arrangements and institutions? Do government's processes and mechanisms reflect and reinforce the pursuit of stability? If incrementalism, as elucidated by Lindblom and Wildavsky, is, in fact, the master mechanism of American government, then, surely, the answer to this question must be intensely affirmative. Consider the budget process. The powers to spend, to tax, and to borrow are the principal means through which the purposes of government are realized. Budgeting puts these powers to work; it is arguably the master decision-making process of government. What does government budgeting do? It stabilizes spending. Government budgets exhibit stability, inertial forces, lines of continuity stretching through time, because precedent drives the process. Budget formulation typically takes current service or operating levels, activity requirements, activity consumption rates ${ }^{10}$ resource requirements, and factor prices as starting points. This base is then modified to generate a spending plan for future periods on the presumption that service/operations levels drive activity requirements and that resource requirements are linked to activity levels via stable activity consumption rates. Since spending plans are based on precedent, they are known to be operationally feasible: they already work (Covaleski, et al. 2003). ${ }^{11}$

One could make a similar case with respect to another of government's ubiquitous decision-making processes, machine bureaucracy. It stabilizes. Machine bureaucracy achieves coordination by standardization of work, outputs, and norms. It is robust in the face of harm, threats, and opportunities (Whitford, 2003). A similar logic applies to the extreme measures often taken by public officials to stabilize service delivery. For example, during New York's fiscal crisis we observed that the City's first response was to cut maintenance. From an outlay perspective this looks like insanity. A properly maintained bridge wears out a rate of 1-2 percent a year; a bridge that isn't maintained at all wears out at a rate of 15-20 percent a year. That's a very costly source of cash. When we asked why, the answer usually went to the need to maintain services. Maintenance can be deferred, at a cost, many government operations can't, they must be provided in real time and they cannot be permitted to fail.

Finally, the distinction outlined here links politics to public policies, both at a macro and a micro level. At a macro-political level it reminds us that citizens,

\footnotetext{
${ }^{10}$ The activity consumption rate is the quantity of each activity that is required to produce one unit of service; the resource consumption rate is the quantity of each resource that is required to perform one instance of each activity.

${ }^{11}$ Annularity is arguably inimical to stability (Andersen \& Mortensen, 2010), but it should be stressed that the adoption of this norm was driven by the search for economy and efficiency in government. Most budget reforms have been justified by that search; most have failed (Rockoff, 1985).
} 
unlike shareholders, have disparate preferences. They care about the means by which outcomes are realized and not merely the outcomes themselves; they care who wins and who loses; and, they have different risk preferences. Majority rule, together with disparate preferences, means that there is no unique, best aggregation of individual wants. Instead, as Shipley and Weingarten (2010) explain, policies result not from the preferences of the citizenry, which are inherently unstable, but are instead structurally induced. One possible implication of this perspective is that, in a well-ordered commercial republic, government would be assigned only those functions that had the pursuit of stability or reliability as their defining feature. And that is what we often observe. A more compelling implication is that, given general risk aversion, Americans would tend to adopt governance processes that induce stability and sustain it, which we have. A third implication is that, if demand for stability/safety is a normal good, over time, as we become richer, democratic governments (Kim, 2007) should tend to confront ever more distant, more intractable risks (Shiller 1998; Hacker 2007), which is why progressives usually win in the long run.

This last observation goes to the micro-political level. That risk management is the basic function of the state implies that risk preferences and attitudes are necessarily central to an understanding of partisan conflicts over who gets what, when, and how. Indeed, there is an extensive and growing literature in political science that takes how much and what kinds of risks people are willing to run to be central question of politics (see, Thompson, Ellis, and Wildavsky, 1990; Ellis and Thompson, 1997; Hood et al. 1999; Thompson, Grendstad, and Selle, 1999; Swedlow, 2011a \& 2011b; Gastil et al. 2011; Ripberger, Jenkins-Smith, and Herron, 2011; Jones, 2011; Lodge and Wegrich, 2011; Lockhart, 2011; Chai et al. 2011).

In conclusion, the approach to value creation outlined here offers a common language for understanding the role of the state in an uncertain world. A general risk assessment model, which takes account of the various kinds of risk confronted by the diversity of government institutions, offers the hope of interdisciplinary consilience between economics and political science, business and public administration, organizational studies and finance. This is an end worth winning if we are to achieve intellectual mastery of our subject. Think about the Zen koan about the blind scholars and the elephant. We are unlikely to make sense of the elephant if we persist in the belief that it is a snake. 


\section{References}

Andersen, Simon Calmar, and Peter B. Mortensen (2010) "Policy Stability and Organizational Performance: Is There a Relationship?" Journal of Public Administration Research and Theory 20(1): 1-22.

Barzelay, Michael (2001) The New Public Management: Improving Research and Policy Dialogue. Berkeley: University of California Press.

Barzelay, Michael (2007) "Learning from Second-Hand Experience: Methodology for Extrapolation-Oriented Case Research.” Governance 20(3): 521-543.

Barzelay, M., and Fred Thompson (2006) "Responsibility Budgeting in the Air Force Materiel Command." Public Administration Review, 66(1): 127-138.

Breton, Albert (1977) "The Theory of Local Government Finance and the Debt Regulation of Local Governments.” Public Finance-Finances publiques 32(1): 16-28.

Breton, Albert (1996) Competitive Governments: An Economic Theory of Politics and Public Finance. New York: Cambridge University Press.

Buiter, Willem (1990) Principles of Budgetary and Financial Policy. Cambridge MA: The MIT Press.

Chai, Sun-Ki, Dolgorsuren Dorj, Kyle Hampton, and Ming Liu (2011) "The Role of Culture in Public Goods and Other Experiments." PS: Political Science \& Politics 44(4): 740-744.

Covaleski, Mark A., John H. Evans III, Joan L. Luft, and Michael D. Shields (2003) "Budgeting Research: Three Theoretical Perspectives and Criteria for Selective Integration.” Journal of Management Accounting Research 15(1): 3-49.

Diewert, Irwin, Denis A. Lawrence, and Fred Thompson. (1998) "The Marginal Costs of Taxation and Regulation," in Handbook of Public Finance. F. Thompson and M. Green (eds). New York: Dekker: 135-173.

Dothan, M., and Fred Thompson (2009a) "A Better Budget Rule." Journal of Policy Analysis and Management 28(3): 463-478.

Dothan, M., and Fred Thompson (2009b) "Optimal Budget Rules: A Proof, Given a Random Walk with Drift.” Public Finance and Management 9(3): 439-469.

Ellis, R.E., and Fred Thompson (1997) "Culture and Environment in the Pacific Northwest." American Political Science Review 91(4): 885-897.

Friedman, M. (1962) Capitalism and Freedom. Chicago: University of Chicago Press.

Friedman, M. (1970) "The Social Responsibility of Business Is to Increase its Profits." New York Times Magazine, 13 September, 32-33, 122, 124, 126.

Frum, David (1994) Dead Right. New York: Basic Books.

Gastil, John, Don Braman, Dan Kahan, and Paul Slovic (2011) "The Cultural Orientation of Mass Political Opinion.” PS: Political Science \& Politics 44(4): 711-714.

Grunwald, Michael (2012) The New New Deal: The Hidden Story of Change in the Obama Era. New York: Simon \& Schuster.

Hacker, Jacob S. (2004) "Privatizing Risk without Privatizing the Welfare State: The Hidden Politics of Social Policy Retrenchment in the United States." The American Political Science Review 98(2): 243-260.

Hacker, Jacob S. (2007) The Great Risk Shift: The New Economic Insecurity and the Decline of the American Dream. New York: Oxford University Press. 
Hammitt, James K., Eric S. Belsky, Jonathan I. Levy, and John D. Graham (1999) "Residential Building Codes, Affordability, and Health Protection: A Risk-Tradeoff Approach.” Risk Analysis 19(6): 1037-1058.

Hefetz, Amir, and Mildred E. Warner (2012) "Contracting or Public Delivery? The Importance of Service, Market, and Management Characteristics." Journal of Public Administration Research \& Theory 22(2): 289-317.

Hochman, H.M., and James D. Rodgers (1969) "Pareto Optimal Redistribution." The American Economic Review 59(4) Part 1: 542-557.

Jones, Michael D. (2011) "Leading the Way to Compromise? Cultural Theory and Climate Change Opinion.” PS: Political Science \& Politics 44(4): 720-725.

Judt, Tony, and Kristina Božić (2010) "The Way Things Are and How They Might Be." London Review of Books 32(6) (25 March) 11-26.

Keeney, R.L. (1997) "Estimating Fatalities Induced by the Economic Costs of Regulations." Journal of Risk and Uncertainty 14(1): 5-23.

Kim, Wonik (2007) "Social Risk and Social Insurance: Political Demand for Unemployment Insurance." Rationality and Society 19(2): 229-254.

Krugman, Paul (2010) "Fiscal Fantasies." New York Times. April 8.

Kunreuther, Howard, and Mark V. Pauly (2006) "Rules Rather than Discretion: Lessons from Hurricane Katrina." Journal of Risk and Uncertainty 33(1): 101-116.

Lockhart, Charles (2011) "Specifying the Cultural Foundations of Consensual Democratic Institutions.” PS: Political Science \& Politics 44(4): 731-735.

Lodge, Martin, and Kai Wegrich (2011) "Arguing about Financial Regulation: Comparing National Discourses on the Global Financial Crisis.” PS: Political Science \& Politics 44(4): 726-730.

Lucas, Robert E. (2003) “Macroeconomic Priorities.” American Economic Review 93(1): 114.

Maltz, E., Fred Thompson, and D.J. Ringold (2011) "Assessing and Maximizing Corporate Social Initiatives: A Strategic View of Corporate Social Responsibility.” Journal of Public Affairs 11(4): 344-352.

Mathur, Ike, Manohar Singh, Fred Thompson, and Ali Nejadmalayeri (2012) "Corporate Governance and Lobbying Strategies." Journal of Business Research. Available online Feb.9, $2012 @$ @ http://dx.doi.org/10.1016/j.jbusres.2012.01.003.

Meyers, R. T. (1998) "Regulatory Budgeting: A Bad Idea whose Time Has Come?" Policy Sciences 31(4): 371-384.

Mirrlees, J., S. Adam, T. Besley, R. Blundell, S. Bond, R. Chote, P. Gammie, P. Johnson, G. Myles, J. and Poterba (2012) "The Mirrlees Review: A Proposal for Systematic Tax Reform." National Tax Journal 65(3): 655-684.

Moss, David A. (2004). When All Else Fails: Government As the Ultimate Risk Manager. Cambridge MA: Harvard University Press.

O’Toole, L. J, Jr., and K. J. Meier (2012) Public Management: Organizations, Governance, and Performance. New York: Cambridge University Press.

Patashnik, Eric M. (1996) "The Contractual Nature of Budgeting: A Transaction Cost Perspective on the Design of Budgeting Institutions." Policy Sciences 29(3): 189212. 
Ramey, Garey, and Valerie A. Ramey (1995) "Cross-Country Evidence on the Link Between Volatility and Growth.” The American Economic Review 85(9): 1138-1151.

Ripberger, Joseph T., Hank C. Jenkins-Smith, and Kerry G. Herron (2011) "How Cultural Orientations Create Shifting National Security Coalitions on Nuclear Weapons and Terrorist Threats in the American Public." PS: Political Science \& Politics 44(4): 715-719.

Rockoff, Hugh (1985) "The Origins of the Federal Budget." The Journal of Economic History 45(2) (June): 377-382. Stable URL: http://www.jstor.org/stable/2121707

Shepsle, Kenneth A., and B.R. Weingast (2012) "Why So Much Stability? Majority Voting, Legislative Institutions, and Gordon Tullock," Unpublished MS, Harvard University, March. Accessed August 24, 2012 @ http://scholar.harvard.edu/ kshepsle/files/Shepsle-Weingast_on_Tullock._Final_Version_3.22.10.pdf

Shiller, R.J. (1998) Macro Markets: Creating Institutions for Managing Society's Largest Economic Risks. New York: Oxford University Press.

Swedlow, Brendon (2011a) “A Cultural Theory of Politics.” PS: Political Science \& Politics 44(4): 703-710.

Swedlow, Brendon (2011b) "Cultural Surprises as Sources of Sudden, Big Policy Change." PS: Political Science \& Politics 44(4): 736-739.

Thompson, Fred (1997) “Toward a Regulatory Budget.” Public Budgeting \& Finance. 17(1) (Spring) 89-98.

Thompson, Fred, and B. Gates (2007) "Betting on the Future with a Cloudy Crystal Ball?" Public Administration Review, 67(5) (Sep-Oct) 825-836.

Thompson, M., R.E. Ellis, and A. Wildavsky (1990) Cultural Theory. Boulder Colo.: Westview Press.

Thompson, M., G. Grendstad, and P. Selle (1999) Cultural Theory as Political Science. New York: Routledge.

Verweij, Marco, Shenghua Luan, and Mark Nowacki (2011) "How to Test Cultural Theory: Suggestions for Future Research.” PS: Political Science \& Politics 44(4): 745-748.

Viscusi, W. Kip (1994) "Mortality Effects of Regulatory Costs and Policy Evaluation Criteria." The RAND Journal of Economics 25(1): 94-109.

Whitford, Andrew B. (2003) "Adapting Agencies: Competition, Imitation, and Punishment in the Design of Bureaucratic Performance." In Politics, Policy and Organizations: Essays on the Scientific Study of Bureaucracy, George Krause and Kenneth J. Meier, eds. Ann Arbor MI: University of Michigan Press, 160-186.

Wildavsky, Aaron (1980) "Richer is Safer.” Public Interest, 60(1): 23-39.

Wildavsky, Aaron (1981) “Richer is Safer.” Financial Analysts Journal 37(2): 19-22. 


\section{KAKO VLADA STVARA VREDNOST?}

Apstrakt: Privatna preduzeća treba da budu okrenuta ka maksimizaciji produktivnosti. Dok bi vlada bi trebalo da bude zadužena za minimiziranje rizika i odgovorna za troškove ili ograničenje produktivnosti. Što se tiče stvaranja vrednosti, vlada bi trebalo da se zalaže za doslednost, koherentnost i transparentnost. Postitizanje konzistentnosti i koherentnosti nasuprot sistemskog i idiosinkratskog rizika traži izradu modela opšte procene rizika koji uzima u obzir različite vrste rizika i koji je suočen sa raznolikošću vladinih institucija. U nedostatku takvog modela, čemu se najbolje možemo nadati je projektovanje i izvođenje politike i prakse koji osiguravaju razumno zadovoljavajuće rezultate bez obzira na to šta budućnost donosi.

Ključne reči: proces, mehanizam, državna potrošnja i oporezivanje, rizik, sistemski rizik, javna uprava. 